\title{
Analysis of autoclaved aerated concrete (AAC) blocks with reference to its potential and sustainability
}

\author{
Mohammad Arif Kamal
}

\begin{abstract}
Arhitecture Section, Aligarh Muslim University, Aligarh India.
Corresponding Author: architectarif@gmail.com
\end{abstract}

Received: 11-06-2020

Accepted: 14-07-2020

\begin{abstract}
The traditional bricks are the main building materials that are used extensively in the construction and building industry. Autoclaved Aerated Concrete blocks are recently one of the newly adopted building materials. The Autoclaved aerated concrete (AAC) is a product of fly ash which is mixed with lime, cement, and water and an aerating agent. The AAC is mainly produced as cuboid blocks and prefabricated panels. The Autoclaved aerated concrete is a type of concrete that is manufactured to contain lots of closed air voids. The AAC blocks are energy efficient, durable, less dense, and lightweight. It is manufactured by adding a foaming additive to concrete in different sizes of molds as per requirement, then wire-cutting these blocks or panels from the resulting 'cake lump' and 'heating them with steam. This process is called as Autoclaving. It has been observed that this material is an ecofriendly building material that is being manufactured from industrial waste and is composed of non-toxic ingredients. In this paper, an overview of AAC blocks with reference to its potential and sustainability as a novel building material has been presented. The paper also presents a comparative cost analysis of AAC Blocks with the Red clay bricks and its suitability and potential use in the construction in the building industry.
\end{abstract}

Key words: AAC blocks; Performance, Potential, Walling system; Sustainability.

\section{Introduction}

The traditional bricks are the main building materials that are used extensively in the construction and building industries in India. Due to the rapid urbanization and expanding interest for development materials, block furnaces have quickly developed which have legitimately or in a roundabout way caused a progression of ecological and medical issues. At a worldwide level, ecological contamination from block making activities adds to the wonders of an Earth-wide temperature boost and environmental change. The different kinds of blocks can be utilized as an option in contrast to the red blocks, to diminish natural contamination and Global warming. AAC blocks might be one of the answers for block substitution. Like froth concrete, Autoclaved Aerated Concrete (AAC) is one of the confirmed green structure materials, which can be utilized for business, modern and private development. It has the basic properties required for use as a structured segment. Because of the lightweight and high solidarity toweight proportion of circulated air through solid items, their utilization brings about an obvious economy in the auxiliary individuals, and along these lines spare concrete and steel support. Fig. 1 shows an AAC block, (brand name as Aerocon blocks).

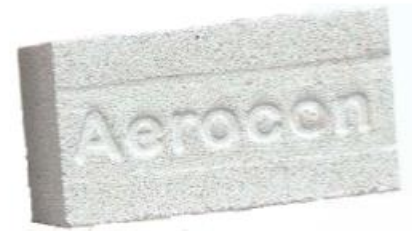

Fig 1. Aerated Autoclaved Concrete (AAC) Blocks. 
The Autoclaved aerated concrete (AAC) was created and developed in 1924 by the Swedish architect Dr. Johan Axel Eriksson, along working with Professor Henrik Kreüger at the Royal Institute of Technology (Rajan, 2013). It is an eco-accommodating structural material that originates from modern waste and is produced by using non-poisonous and non-toxic ingredients. With $\mathrm{AAC}$, the development procedure can be around 20 percent quicker. It weighs just around 50 percent of a standard solid square and has high warm protection and is acousticsaccommodating. It additionally has preferable imperviousness to fire over fly debris and is nonburnable. It's non-hypersensitive and henceforth keeps up the nature of air inside a structure without changing its properties after some time. With AAC, the development procedure can be around 20 percent quicker. It weighs just around 50 percent of a standard solid block and has high thermal insulation and acoustical properties. It's non-unfavorably susceptible and consequently keeps up the nature of air inside a structure without changing its properties after some time. The utilization of AAC block can lessen development costs by about 2.5 percent for structures, for example, schools and medical clinics, and diminish the running expenses of lodging and places of business by to 30 to 40 percent after some time. Fig. 1 shows an AAC block, (brand named as Aerocon blocks).As indicated by one report, AAC now represents over $40 \%$ of all development in the United Kingdom and over $60 \%$ of development in Germany (Schnitzler, 2016).

\section{Raw Materials Used In Manufacturing of AAC Blocks}

As compared to most other concrete building applications in the construction industry, Aerated Autoclaved Concrete (AAC) is created utilizing no total bigger than sand. Quartz sand, calcined gypsum, lime (mineral) as well as concrete and water are utilized as a coupling specialist. In certain nations, similar to India and China, fly debris produced from thermal power plants and having $50-65 \%$ silica content is used as an aggregate. There are many raw materials which are used in the manufacturing of AAC blocks. The Aerated Autoclaved Concrete (AAC) comprises of Flyash or sand as the major component. The percentage proportion of Fly ash is $65-70 \%$ and coarse sand is 55-65\%. The percent proportion of cement 53 GRADE OPC with Flyash is $6-15 \%$ and with sand is $10-20 \%$, The percent proportion of Lime with Flyash is $18-25 \%$ and with sand $20-30 \%$, The percent proportion of Gypsum with Flyash is 3-5\% and with sand is $2-3 \%$. The percent portion Aluminium powder paste $\left(600 \mathrm{~kg} / \mathrm{m}^{3}\right)$ is $8 \%$ or $0.05 \%-0.08 \%$ by volume (contingent upon the pre-indicated thickness). The water percent with Flyash is 0.6 and with sand is $0.65 \%$.

\section{Specifications and Performance Summary of AAC Blocks}

The product specification and its performance summary of AAC blocks are summarized as below (Kamal, 2016):

\subsection{Appearance}

The Autoclaved aerated concrete (AAC) is light-hued and contains numerous small voids that can be observed when taken a gander at intently. The gas used to 'froth' the solid during the manufacturing process is hydrogen from the chemical reaction from the Aluminum paste with alkaline soluble components in the cement concrete. These air pockets add to the material's protecting properties. In contrast to stonework, there is no immediate way for water to go through the material; be that as it may, it can suck up dampness and a suitable covering is required to forestall water infiltration.

\subsection{Size and Density}

The Autoclaved aerated concrete (AAC) blocks are made of $625 \mathrm{~mm}$ length, $250 \mathrm{~mm}$ tallness, and of different thicknesses: $100,125,150,200,225,250,300 \mathrm{~mm}$ with a resistance of $\pm 1.5 \mathrm{~mm}$. The thickness of the block is 600 to $650 \mathrm{~kg} / \mathrm{cum}$, though the blocks have a thickness of 1750 to 2000 
$\mathrm{kg} / \mathrm{cum}$. The density of wet blocks is around $800 \mathrm{~kg} / \mathrm{cum}$ as compared to that of red clay bricks $(2400 \mathrm{~kg} / \mathrm{cum})$.

\subsection{Structural Capability}

The compressive quality of Autoclaved aerated concrete (AAC) blocks is excellent. The compressive quality is from 35 to $50 \mathrm{~kg} / \mathrm{cm}^{2}$ (according to IS: 2185). Although it is one-fifth the thickness of typical solid it despite everything has a large portion of the bearing quality, and loadbearing structures up to three stories high can be securely raised with AAC blockwork. The AAC is 3-4 times lighter than traditional bricks, therefore, easier and cheaper to transport. Usage reduces the overall dead load of a building, thereby allowing the construction of taller buildings. Entire building structures can be made in AAC from walls to floors and roofing with reinforced lintels, blocks, and floor, wall and roofing panels available from the manufacturer. AAC floor panels can be used to make non-loadbearing concrete floors that can be installed by carpenters. Lightweight blocks diminish the mass of a structure, along these lines diminishing the effect of tremor on a structure.

\subsection{Thermal mass}

The thermal mass performance of Autoclaved aerated concrete (AAC) is dependent on the climate in which it is used. With its mixture of concrete and air pockets, AAC has a moderate overall level of thermal mass performance. Its use for internal walls and flooring can provide significant thermal mass. The temperature moderating thermal mass is most useful in climates with high cooling needs.

\subsection{Insulation}

The Autoclaved aerated concrete (AAC) has very good thermal insulation qualities relative to another masonry. A $200 \mathrm{~mm}$ thick AAC wall gives an R-value rating of 1.43 with $5 \%$ moisture content by weight. With a $2-3 \mathrm{~mm}$ texture coating and $10 \mathrm{~mm}$ plasterboard internal lining it achieves an R rating of 1.75 (a cavity brick wall achieves 0.82 ). A texture-coated $100 \mathrm{~mm}$ AAC veneer on a lightweight $70 \mathrm{~mm}$ or $90 \mathrm{~mm}$ frame filled with bulk insulation achieves a higher $\mathrm{R}$ rating than an otherwise equivalent brick veneer wall (see Insulation; Lightweight framing). Relative to their thickness, The Thermal Conductivity of AAC blocks is $0.16 \mathrm{~kW} / \mathrm{m}^{\circ} \mathrm{C}$ against 0.70 of bricks, thus recurring energy cost is reduced in air conditioning. AAC panels provide less insulation than AAC blockwork, e.g. a $100 \mathrm{~mm}$ blockwork AAC wall has a dry state R-value of 0.86 , and a $100 \mathrm{~mm}$ AAC wall panel has a dry state R-value of 0.68 .

\subsection{Sound Insulation}

With its closed air pockets, Autoclaved aerated concrete (AAC) can provide very good sound insulation. It has superior sound absorption qualities due to the porous structure of blocks. Combining the AAC wall with an insulated asymmetric air cavity system gives a wall excellent sound insulation property. AAC offers sound attenuation of about $42 \mathrm{~dB}$, blocking out all major sounds and disturbances. The Sound Reduction Index is $45 \mathrm{~dB}$ for $200 \mathrm{~mm}$ thick block walls (against 50 for $230 \mathrm{~mm}$ thick wall). It is ideal for schools, hospitals, hotels, offices, multi-family housing, and other structures that require acoustic insulation.

\subsection{Fire and Vermin Resistance}

Autoclaved aerated concrete (AAC) is inorganic, incombustible and does not explode; it is thus well suited for fire-rated applications. Depending on the application and the thickness of the blocks or panels, fire ratings up to four hours can be achieved. AAC is non-combustible and fireresistant up to $1600^{\circ} \mathrm{C}$. It can withstand up to 6 hours of direct exposure. Due to the structure of 
blocks, AAC cannot be damaged or infested by termites and other pests. It does not attract rodents or other pests nor can it be damaged by such.

\subsection{Durability and Moisture Resistance}

The purposely lightweight nature of Autoclaved aerated concrete (AAC) makes it prone to impact damage. With the surface protected to resist moisture penetration, it is not affected by harsh climatic conditions and does not degrade under normal atmospheric conditions. The level of maintenance required by the material varies with the type of finish applied. The porous nature of AAC can allow moisture to penetrate to depth but the appropriate design (damp proof course layers and appropriate coating systems) prevents this happening. AAC does not easily degrade structurally when exposed to moisture, but its thermal performance may suffer. Several proprietary finishes (including acrylic polymer-based texture coatings) give durable and waterresistant coatings to AAC blockwork and panels. They need to be treated similarly with acrylic polymer-based coatings before tiling in wet areas such as showers.

\subsection{Water Absorption}

In Autoclaved Aerated Concrete (AAC) curing takes place at a high temperature and high pressure in saturated steam. During curing, part of the siliceous material (flyash) reacts chemically with the calcareous ingredients such as lime liberated by the hydration of cement to form a Micro-Crystalline structure of Tobermorite with much lower specific surface and is characterized by pores formed by the release of $\mathrm{H}_{2}$ gas during Casting-Rising stage of production.

\subsection{Toxicity and Breathability}

The aerated nature of AAC facilitates breathability. There are no toxic substances and no odor in the final product. However, AAC is a concrete product and calls for precautions similar to those for handling and cutting concrete products. It is advisable to wear personal protective equipment such as gloves, eyewear, and respiratory masks during cutting, due to the fine dust produced by concrete products. If low-toxic, vapor-permeable coatings are used on the walls, and care is taken not to trap moisture where it can condense, AAC may be an ideal material for homes for the chemically sensitive.

\subsection{Constructability, Availability, and Cost}

Although AAC is relatively easy to work, it is one-fifth the weight of concrete comes in a variety of sizes and is easily carved, cut and sculpted, it nevertheless requires careful and accurate placement: skilled trades and good supervision are essential. Different sizes of blocks help reduce the number of joints in wall masonry. Lighter blocks make construction easier and faster. It reduces construction time by $20 \%$. They are easy to install. AAC sets and hardens quickly. Blocks can be easily cut, drilled, nailed, milled, and grooved to fit individual requirements. Thickbed mortar is more forgiving but is uncommon and not the industry preferred option. It also simplifies hydro-sanitary and electrical installations, such as pipes or ducts, which can be installed after the main construction is complete. The construction process with AAC produces little waste as blockwork offcuts can be reused in wall construction.

\section{Autoclaved Aerated Concrete (AAC) Block Walling System}

The AAC blocks are generally used in the wall masonry. The process of laying and construction of a complete wall unit is summarized in the following steps (Majumdar, 2019). 


\subsection{Laying of Blocks}

In laying AAC blocks, the procedure is the same as that for conventional half brickwork except that the block should be slightly wet with a sprinkler before use and not soaked as in case of bricks.

a. Before laying the first course the alignment of the wall is marked over the DPC.

b. The blocks for $1^{\text {st }}$ course should first be laid dry without mortar along a stretched thread between properly located corners of the wall to determine the correct position of the blocks, including those of cross walls joining it and also to adjust their spacing within the wall length.

c. When the blocks are set in a proper position, the two corner blocks are removed. A specified mortar bed is spread for the required bed thickness $(10 \mathrm{~mm})$.

d. The blocks are laid back in place with true level and plumb.

e. The thread is then stretched tightly along with the faces of the two corner blocks and the faces of the intermediate blocks are adjusted to coincide with the thread line.

f. Each intermediate block is removed and re-laid with mortar.

g. After every three or four blocks, layers are laid, their correct alignment level and verticality are checked.

h. In the vertical joints, the mortar is applied only on the face of the blocks.

\subsection{Electrical and Plumbing Installations}

Electrical and plumbing installations in AAC masonry are placed in routed chases. Care should be taken when laying out chases to ensure that the structural integrity of the AAC elements is maintained. Do not cut reinforcing steel or reduce the structural thickness of the AAC elements except where permitted by the designer. In vertically spanning AAC elements, horizontal routing should be permitted only in areas with low flexural and compressive stresses. In horizontally spanning AAC elements, vertical routing should be minimized.

\subsection{Exterior Finishes}

Unprotected exterior AAC deteriorates when exposed to cycles of freezing and thawing while saturated. To prevent such freeze-thaw deterioration, and to enhance the aesthetics and abrasion resistance to AAC, exterior finishes should be used. They should be compatible with the underlying AAC in terms of thermal expansion and modulus of elasticity and should be vapor permeable. Many different types of exterior finishes are available. Polymer-modified stuccos, paints, or finish systems are the most common exterior finish for AAC. They increase the AAC's water-penetration resistance while allowing the passage of water vapor. Heavy acrylic-based paints containing aggregates are also used to increase abrasion resistance. There is generally no need to level the surface, and horizontal and vertical joints may be chamfered as an architectural feature or may be filled.

\subsection{Interior Finishes}

Interior finishes are used to enhance the aesthetics and durability of AAC. They should be compatible with the underlying AAC in terms of thermal expansion and modulus of elasticity and should be vapor permeable.

a. Many different types of interior finishes are available. Interior AAC wall panels may have a thin coat of a mineral-based plaster to achieve a smooth finished surface. Lightweight interior gypsum-based plaster may provide a thicker coating to level and straighten walls, and to provide a base for decorative interior paints or wall finishes. Interior 
plasters have bonding agents to enhance their adhesion and flexibility and are commonly installed by either spraying or troweling.

b. For commercial applications requiring high durability and low maintenance, acrylicbased coatings are often used. Some contain aggregates to enhance abrasion resistance.

c. When ceramic wall tile is to be applied over AAC, surface preparation is normally necessary only when the AAC surface requires leveling. In such cases, a Portland cement or gypsum-based parge coat is applied to the AAC surface before setting the ceramic tile. The ceramic tile should then be adhered to the parged wall using either a cement-based thin-set mortar or an organic adhesive. In moist areas such as showers, only a Portland cement-based parge coat should be used, and the ceramic tile should be set with cementbased, thin-set mortar only.

\subsection{Service Lines}

For concealed or piping, a block wall can be chased using hand or electric router. Depths of vertical chases should be limited to one-third of the wall thickness and horizontal chases to onesixth of the wall thickness. Holes in a block wall can be made with a standard hand or electric drill. The chases shall be refilled with a leaner mortar and chicken mesh shall be applied to that area and cured.

\subsection{Lintels}

Precast or cast-in-situ concrete lintels can be used in block masonry, over all openings. Lintels shall always rest on a full block with a minimum bearing as under. Below the openings, the RCC band should be provided with reinforcement to avoid diagonal tension cracks. The bond beam to be extended up to $300 \mathrm{~mm}$ from window corners both sides.

\subsection{Plastering}

Followings are the points that should be considered while plastering the AAC walls:

a. Do not soak the wall before plastering. The wall shall be moistened evenly before applying the plaster. A fog spray is recommended for this purpose.

b. For external plastering has to be carried out in two coats, apply SBR coating with sand on the block surface will enhance the bonding and minimize the thickness of plastering.

c. It is recommended to use cement mortar 1:6 for internal \& external plastering works and preferably use PPC cement for masonry and plastering works to minimize shrinkage cracks.

d. Plastering thickness can be minimized to $10 \mathrm{~mm}$ and $15 \mathrm{~mm}$ for internal and external walls.

\subsection{Precautions while Laying the AAC Masonry blocks}

The cracks occurring in block masonry and plastering are of any structural problem involving stability and safety to the structure. But it is advised to minimize the same to have good appearance and maintenance-free.
a. Do not store the blocks on an unleveled surface
b. Do not use wet blocks for masonry construction
c. Do not make the holes on block masonry for scaffolding supports
d. Do not soak the blocks before use
e. Do not hammer the block masonry for service lines, chases, etc.
f. Do not completely wet the block masonry before plastering works
g. Do not chase the blocks back to back for lesser thickness blocks. 


\section{Advantage of Autoclaved Aerated Concrete (AAC) Block}

Autoclaved aerated concrete (AAC) has many advantages as compared to other cement concrete materials. The basic advantage is that it is cost-efficient and Eco-friendly with having a low environmental impact. In the manufacturing of AAC blocks, the topsoil of the earth's surface is not used; therefore it emits very low carbon dioxide as compared to red clay bricks. Since AAC blocks are an industrial product manufactured with machines, the quality of the end products is very good, uniform, and consistent. The blocks are even and well finished from all sides, therefore the thickness of wall plaster is reduced. Due to its lightweight, there will also be a reduction of dead weight in the structural system, which will lead to the saving of steel and concrete. Also this lead to construction more stories or taller buildings. The economy is achieved in multistoried, especially buildings by using AAC blocks as compared to red clay bricks due to a significant reduction in the dead weight of the structure; and hence it reduces the cost of the RCC framed structure.

The AAC blocks have a lot of pores and voids; hence it provides better sound absorption and insulation as compared to red clay bricks or concrete blocks. The AAC blocks have a low thermal conductivity which is approximately $0.24 \mathrm{Kw}-\mathrm{M} /{ }^{\circ} \mathrm{C}$, which results in the saving of electricity costs by $30 \%$, which is required for heating and cooling of the house. The manufacturing process of AAC blocks is non-polluting. The by-product from the manufacturing industry is only steam. All the ingredients to manufacture the AAC blocks are non-toxic and safe. The AAC blocks are fire resistant and non-combustible. They can tolerate up to 6 hours of direct exposure to fire. The AAC blocks have air voids and hence have better fire-resisting property compared to red clay bricks. The melting point of the AAC blocks is over $1600{ }^{\circ} \mathrm{C}$ more than twice the typical temperature in building fire $650^{\circ} \mathrm{C}$. The AAC blocks are easy to work with i.e they can be easily cut nailed and drilled and can be fitted to the individual requirements which give more design flexibility. It cannot be rotten easily since it is pest and termite-proof. The AAC walling system has a simplified hydro-sanitary and electrical installations, such as pipes or ducts, which can be installed after the main construction is completed. It also has low maintenance and it reduces the operating and maintenance cost by $30 \%$ to $40 \%$. The chemical mortars can be used for joining the AAC blocks in masonry work; hence this reduces the material consumption for cement mortar and also there is no need for the curing. The AAC blocks are suitable both for non-load bearing strictures and also for reinforced cement concrete structure in partition walls.

\section{Disadvantage of Autoclaved Aerated Concrete (AAC) Block}

There are many advantages of using AAC block, which has made this material a very suitable and sustainable material in the building and construction sector. But there are also a few disadvantages of using AAC blocks. It has been observed that the Aircrete cracks after installation in the rainy season, which can be avoided by reducing the strength of the mortar and ensuring the blocks, are dry during and after installation. The AAC blocks should be handled carefully then as compared to red clay bricks to avoid breakages since it is little brittle. Due to its brittle nature, it requires long thin screws when fitting cabinets and wall hangings. The initial cost of the manufacturing industry is a bit high. There are not many factories, which are producing AAC blocks; therefore it is not very easily available. 


\section{Comparative Analysis of AAC Block, Clay Brick and CLC Block}

The comparative analysis of Autoclaved Aerated Concrete (AAC) blocks, Red clay bricks, and Cellular Light Weight Concrete (CLC) blocks are summarized in Table 1:

Table 1. Comparison of AAC Block, Clay Bricks, and CLC Blocks (Kulbhushan et al, 2018).

\begin{tabular}{|c|c|c|c|c|}
\hline S. No & Parameter & AAC Blocks & Clay Red Bricks & CLC Blocks \\
\hline 1 & Raw Materials & $\begin{array}{l}\text { Cement, fly ash, } \\
\text { water, and Air } \\
\text { entraining agents }\end{array}$ & Locally available clay & $\begin{array}{l}\text { Cement, lime, } \\
\text { specially grinded } \\
\text { sand, foam }\end{array}$ \\
\hline 2 & Size & 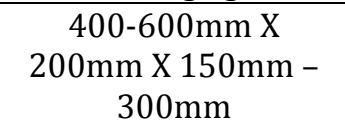 & $\begin{array}{c}225 \mathrm{~mm} \times 75 \mathrm{~mm} X \\
100 / 150 \mathrm{~mm}\end{array}$ & $\begin{array}{c}400-600 \times 200 \times \\
100 / 150 / 200 \mathrm{~mm}\end{array}$ \\
\hline 3 & Variation Size & $1.5 \mathrm{~mm}(+/-)$ & $5 \mathrm{~mm}(+/-)$ & $5 \mathrm{~mm}(+/-)$ \\
\hline 4 & $\begin{array}{c}\text { Compressive } \\
\text { Strength (As per IS } \\
\text { codes) }\end{array}$ & $3-4 \mathrm{~N} / \mathrm{mm}^{2}$ & $3.5 \mathrm{~N} / \mathrm{mm}^{2}$ & $2-2.5 \mathrm{~kg} / \mathrm{cm}^{2}$ \\
\hline 5 & $\begin{array}{l}\text { Dry Density (As per } \\
\text { IS codes) }\end{array}$ & $\begin{array}{l}550-650 \mathrm{~kg} / \mathrm{m}^{3} \text { Its } \\
\text { one-third of the } \\
\text { weight of clay brick } \\
\text { which makes it easy } \\
\text { to lift and transport }\end{array}$ & $1800 \mathrm{~kg} / \mathrm{m}^{3}$ & $800 \mathrm{~kg} / \mathrm{m}^{3}$ \\
\hline 6 & Cost-Benefit & $\begin{array}{c}\text { For high rise } \\
\text { buildings, there will } \\
\text { be a reduction of } \\
\text { Deadweight which } \\
\text { leads to saving in } \\
\text { Concrete and steel } \\
\text { quantities. }\end{array}$ & $\begin{array}{l}\text { As easily available in } \\
\text { the local market } \\
\text { hence it is beneficial } \\
\text { for low rise structure. }\end{array}$ & $\begin{array}{c}\text { For high rise } \\
\text { buildings, there will } \\
\text { be a reduction of } \\
\text { Deadweight which } \\
\text { leads to saving in } \\
\text { Concrete and steel } \\
\text { quantities. }\end{array}$ \\
\hline 7 & $\begin{array}{l}\text { Fire Resistance } \\
\text { (8" Wall) }\end{array}$ & Up to 4 Hours & Around 2 Hours & Around 4 Hours \\
\hline 8 & $\begin{array}{l}\text { Quality of End } \\
\text { Product }\end{array}$ & $\begin{array}{l}\text { Factory-made } \\
\text { product. So the } \\
\text { quality of the end } \\
\text { product is consistent } \\
\text { and good }\end{array}$ & $\begin{array}{l}\text { Locally made } \\
\text { products. Quality } \\
\text { depends on various } \\
\text { parameters like } \\
\text { quality of raw } \\
\text { materials used, the } \\
\text { process of } \\
\text { manufacture, etc., }\end{array}$ & $\begin{array}{l}\text { The quality of the end } \\
\text { product depends on } \\
\text { the foam used and } \\
\text { degree of quality } \\
\text { control }\end{array}$ \\
\hline 9 & Sound Insulation & $\begin{array}{c}\text { Better Sound } \\
\text { absorption } \\
\text { /insulation as } \\
\text { compared to bricks }\end{array}$ & Normal & $\begin{array}{c}\text { Better Sound } \\
\text { absorption } \\
\text { /insulation as } \\
\text { compared to bricks }\end{array}$ \\
\hline 10 & Energy Saving & $\begin{array}{c}\text { Low thermal } \\
\text { conductivity }(0.24 \\
\mathrm{Kw}-\mathrm{M} / \mathrm{C}) \text { helps in } \\
\text { saving electricity } \\
\text { costs } 30 \% \text { for heating } \\
\text { and cooling of the } \\
\text { house }\end{array}$ & $\begin{array}{l}\text { High thermal } \\
\text { Conductivity ( } 0.81 \\
\text { Kw-M/C). So no } \\
\text { significant cost } \\
\text { savings }\end{array}$ & $\begin{array}{c}\text { Low thermal } \\
\text { conductivity }(0.32 \\
\text { Kw-M/C) helps in } \\
\text { saving electricity } \\
\text { costs } 30 \% \text { for heating } \\
\text { and cooling of the } \\
\text { house }\end{array}$ \\
\hline 11 & $\begin{array}{l}\text { Environmental } \\
\text { Friendliness }\end{array}$ & $\begin{array}{l}\text { In AAC Block there is } \\
\text { no topsoil } \\
\text { consumption and it } \\
\text { emits very low } \\
\text { Carbon dioxide as } \\
\text { compared to Red clay }\end{array}$ & $\begin{array}{c}\text { One sq ft of carpet } \\
\text { area with clay brick } \\
\text { walling will consume } \\
25.5 \mathrm{~kg} \text { of topsoil } \\
\text { (approx.). It damages } \\
\text { the environment }\end{array}$ & $\begin{array}{l}\text { In CLC Block there is } \\
\text { no topsoil } \\
\text { consumption and it } \\
\text { emits very low } \\
\text { Carbon dioxide as } \\
\text { compared to Red clay }\end{array}$ \\
\hline
\end{tabular}




\begin{tabular}{|c|c|c|c|c|}
\hline & & $\begin{array}{l}\text { bricks while } \\
\text { manufacturing }\end{array}$ & & $\begin{array}{l}\text { bricks while } \\
\text { manufacturing. }\end{array}$ \\
\hline 12 & $\begin{array}{c}\text { Internal and External } \\
\text { Plaster }\end{array}$ & $\begin{array}{l}\text { As these bricks have } \\
\text { dimensional } \\
\text { accuracy, the internal } \\
\text { and external plaster } \\
\text { thickness can be } \\
\text { reduced }\end{array}$ & $\begin{array}{l}\text { Requires thick } \\
\text { plaster surface as } \\
\text { there are variations } \\
\text { in the dimensions }\end{array}$ & $\begin{array}{l}\text { As these bricks have } \\
\text { dimensional } \\
\text { accuracy, the internal } \\
\text { and external plaster } \\
\text { thickness can be } \\
\text { reduced }\end{array}$ \\
\hline 13 & Cost of Construction & $\begin{array}{c}1 \text { Cum costs - Rs. } \\
4200 /-\end{array}$ & $\begin{array}{c}1 \text { Cum costs - Rs. } \\
2440 /-\end{array}$ & $\begin{array}{c}1 \text { Cum costs - Rs. } \\
4000 /-\end{array}$ \\
\hline 14 & Joining Process & $\begin{array}{l}\text { Chemical mortars can } \\
\text { be used for joining } \\
\text { the brick. This } \\
\text { reduces the material } \\
\text { consumption for } \\
\text { cement and avoids } \\
\text { curing process }\end{array}$ & $\begin{array}{l}\text { The traditional } \\
\text { mortar needs to be } \\
\text { used and the } \\
\text { brickwork should be } \\
\text { cured at least for } 7 \\
\text { days before } \\
\text { plastering }\end{array}$ & $\begin{array}{l}\text { Chemical mortar can } \\
\text { be used for joining } \\
\text { the brick. This } \\
\text { reduces the material } \\
\text { consumption of } \\
\text { cement \& avoids the } \\
\text { curing process. }\end{array}$ \\
\hline 15 & Availability & $\begin{array}{l}\text { The factory setup } \\
\text { cost is high. Not many } \\
\text { factories, so } \\
\text { availability is a } \\
\text { concern. }\end{array}$ & $\begin{array}{l}\text { Available locally in all } \\
\text { cities and villages. }\end{array}$ & $\begin{array}{l}\text { The factory setup } \\
\text { cost is low as } \\
\text { compared to AAC. It } \\
\text { also takes a long time } \\
\text { to produce if steam } \\
\text { curing is not used. } \\
\text { Timely availability is } \\
\text { a concern. }\end{array}$ \\
\hline 16 & Thermal Insulator & $\begin{array}{l}\text { AAC Blocks are good } \\
\text { thermal insulator if } \\
\text { cooling is a major } \\
\text { component, monthly } \\
\text { expenses it will save } \\
\text { cost for an entire } \\
\text { lifetime }\end{array}$ & $\begin{array}{l}\text { It has low thermal } \\
\text { insulation as } \\
\text { compared to AAC and } \\
\text { CLC Block }\end{array}$ & $\begin{array}{l}\text { CLC Blocks are good } \\
\text { thermal insulator if } \\
\text { cooling is a major } \\
\text { component, monthly } \\
\text { expenses it will save } \\
\text { cost for an entire } \\
\text { lifetime }\end{array}$ \\
\hline 17 & Tax Contribution & $\begin{array}{c}\text { Contributes to } \\
\text { Government taxes in } \\
\text { form of Central, } \\
\text { Excise, and VAT }\end{array}$ & No Tax Contribution & $\begin{array}{c}\text { Contributes to } \\
\text { Government taxes in } \\
\text { form of Central } \\
\text { Excise and VAT }\end{array}$ \\
\hline 18 & Cylindrical Structures & $\begin{array}{c}\text { For Cylindrical } \\
\text { structure, these } \\
\text { blocks are not much } \\
\text { useful }\end{array}$ & $\begin{array}{l}\text { Cylindrical manholes } \\
\text { need small size of } \\
\text { bricks so that the } \\
\text { curvature can be } \\
\text { formed hence Red } \\
\text { clay bricks are useful }\end{array}$ & $\begin{array}{c}\text { For Cylindrical } \\
\text { structure, these } \\
\text { blocks are not much } \\
\text { useful }\end{array}$ \\
\hline 19 & Water Absorption & $\begin{array}{l}\text { Absorb } 12-15 \% \text { by } \\
\text { the total volume of } \\
\text { AAC blocks }\end{array}$ & $\begin{array}{l}\text { Absorb } 17-20 \% \text { by } \\
\text { the total volume of } \\
\text { red clay brick }\end{array}$ & $\begin{array}{l}\text { Absorb } 12-15 \% \text { of } \\
\text { water by the total } \\
\text { volume of Block }\end{array}$ \\
\hline 20 & Range of Application & $\begin{array}{l}\text { They are suitable for } \\
\text { non-load-bearing or } \\
\text { RCC structure in the } \\
\text { partition wall }\end{array}$ & $\begin{array}{c}\text { They are useful in } \\
\text { both load-bearing } \\
\text { and non-load bearing } \\
\text { structure }\end{array}$ & $\begin{array}{c}\text { They are suitable for } \\
\text { non-load-bearing or } \\
\text { RCC structure in the } \\
\text { partition wall }\end{array}$ \\
\hline
\end{tabular}

\section{Cost Comparative Analysis of AAC Block, Clay Brick and CLC Block}

The cost comparative analysis of brickwork in masonry and plaster for AAC blocks, Red clay bricks, and Cellular Light Weight Concrete (CLC) blocks are summarized in Table 2 and Table 3 respectively (Jain et al., 2018). 
Table 2. Cost Comparative Analysis for AAC Blocks and Clay Brick Masonry for $1 \mathrm{~m}^{3}$ [1:4]

\begin{tabular}{|c|c|c|c|}
\hline S. No. & Parameters & Clay Red Bricks & AAC Blocks \\
\hline \hline 1 & Quantity Analysis & 200mmx 100mm x 100mm & $600 \mathrm{~mm} \times 200 \mathrm{~mm} \times 200 \mathrm{~mm}$ \\
\hline 2 & No. of bricks / blocks & 500 & 37 \\
\hline 3 & Mortar Quantity & $0.2766 \mathrm{~m}^{3}$ & $0.1344 \mathrm{~m}^{3}$ \\
\hline 4 & No. of begs of cement & 1.65 & 1.0 \\
\hline 5 & Quantity of Sand & $0.221 \mathrm{~m}^{3}$ & $0.1075 \mathrm{~m}^{3}$ \\
\hline 6 & Quantity of Water & $31 \mathrm{Litres}^{2}$ & 16 Litres \\
\hline 7 & Rate Analysis & $\begin{array}{r}5252.00 \text { Rs. } / \mathrm{m}^{2} \text { (As per MP } \\
\text { PWD SOR building work 2014 } \\
\text { clause no.6.3) }\end{array}$ & $\begin{array}{c}\text { PWD SOR building work 2014 } \\
\text { clause no.6.27) }\end{array}$ \\
\hline
\end{tabular}

Table 3. Cost Comparison for Plasterwork for AAC Blocks and Clay Brick for $1 \mathrm{~m}^{3}$ [1:4]

\begin{tabular}{|c|c|c|c|}
\hline S. No. & Parameters & Clay Red Bricks & AAC Blocks \\
\hline 1 & $\begin{array}{c}\text { The volume of mortar for } \\
\text { plaster }\end{array}$ & $1.8 \mathrm{~m}^{3}$ & $1.0 \mathrm{~m}^{3}$ \\
\hline 2 & $\begin{array}{l}\text { The volume of mortar by } 25 \% \\
\text { for wastage and frog filling }\end{array}$ & $2.25 \mathrm{~m}^{3}$ & $1.25 \mathrm{~m}^{3}$ \\
\hline 3 & Quantity of cement & $0.45 \mathrm{~m}^{3}$ & $0.25 \mathrm{~m}^{3}$ \\
\hline 4 & No. of begs of cement & 13.5 & 7.5 \\
\hline 5 & Quantity of Sand & $1.8 \mathrm{~m}^{3}$ & $1.0 \mathrm{~m}^{3}$ \\
\hline 6 & Quantity of Water & 236.25 Liters & 131.25 Liters \\
\hline 7 & Rate Analysis & $\begin{array}{c}171.00 \text { Rs./ } \mathrm{m}^{2} \text { (As per MP } \\
\text { PWD SOR building work } 2014 \\
\text { clause no.13.6) }\end{array}$ & $\begin{array}{c}91.10 .00 \text { Rs./ } \mathrm{m}^{2} \text { (As per } \\
\text { MESSOR building work } 2010 \\
\text { item no. } 14001 \text { ) }\end{array}$ \\
\hline
\end{tabular}

\section{Environmental Benefits of AAC Blocks}

The Autoclaved Aerated Concrete (AAC) is an eco-friendly material that has many environmental benefits. The weight of the AAC block is around one-fourth to one-fifth that of concrete based on volume. The manufacturing of AAC blocks has the same greenhouse gas environmental impact and has the same embodied energy as that of concrete block. The AAC blocks or panels have lower embodied energy per square meter than a concrete alternative building material. The AAC block and panels have more insulation value and thus it has low energy usage for heating and cooling loads requirement. The total energy used in manufacturing the ACC blocks is around 50\% less than that of manufacturing other prefabricated building components and products. As compared to regular cement concrete building products, AAC reduces around one-third of the environmental waste. The Autoclaved Aerated Concrete (AAC) blocks and panels have proven to be more durable, provide thermal insulation and structural requirements, and also have major economic and environmental benefits as compared to other traditional building components and products. Thus Autoclaved aerated concrete can be said to a suitable and potential eco-friendly building material, which is beneficial for the environment, which fulfills the requirement for the construction of sustainable architecture and construction (Andrews, 2019).

\section{Conclusions}

The Autoclaved Aerated Concrete (AAC) is a novel and one of the most suitable and sustainable building materials in the present building construction industry. AAC blocks are a result of 
productive use of recycled industrial waste i.e. fly ash, hence this material can be classified as a sustainable building material. The production price of AAC blocks at the manufacturing unit is from Rs. 3200/- to Rs. 3600/ per cubic meter as per the rates in India in the year 2019. The inherent properties of AAC blocks result in fast and efficient construction techniques. Hence the Autoclaved Aerated Concrete (AAC) has become an efficient building construction material which is being used in a wide range of residential, commercial and industrial buildings and it has been used in the Gulf countries for the last 40 years and in Europe for since 70 years, and in Australia and South America for the past 20 years. According to a report, the AAC blocks are used more than $60 \%$ of construction in Germany, and in England approximately $40 \%$ of all construction industry (Andrews, 2019). Since the AAC blocks use readily available raw materials in the manufacturing process, have excellent durability, are energy efficient, are cost-effective, and also can be recycled, therefore Autoclaved Aerated Concrete (AAC) can be said to be a green and sustainable building material.

\section{References}

Andrews A. (2019). Global Autoclaved Aerated Concrete Market Outlook: Trend and Opportunity Analysis, Competitive Insights, Actionable Segmentation and Forecast 2023, Research Report, Energias Market Research, Buffalo, USA.

Jain U., Jain M., \& Mandaokar S., (2018). Comparative Study of AAC Blocks and Clay Brick and Costing, International Journal of Research in Engineering, Science and Management, 1(9), 539-543.

Kamal Arif M. (2016), Autoclaved Aerated Concrete (AAC): A Sustainable Building Material [Online] Available from http://www.masterbuilder.co.in/autoclaved-aerated-concrete-aaca-sustainablebuilding-material/, accessed on 10 May 2020.

Kulbhushan K., Kumar S., Chaudhary R., Ahmad S., Gupta S., \& Chaurasia R. (2018). A Contextual Analysis of the Advantages by Using Lightweight Concrete Blocks as Substitution of Bricks, International Research Journal of Engineering and Technology (IRJET), 5(2), 926-931.

Majumdar B. (2019). New Building Materials and Technologies, Vol. IV, Compendium of New Building Technologies, Indian Building Congress, New Delhi, India.

Rajan N. (2013). Five green building blocks, [Online] Available from http://www.thehindu.com/features/homes-and-gardens/5-green-building blocks/article4813910.ece, accessed on 20 May 2020.

Schnitzler S. (2016), Autoclaved Aerated Concrete as a Green Building Material, UC Davis Extension, Switzerland. 